\title{
SCHEMATYZMY KOŚCIOŁÓW KATOLICKICH OBRZĄDKÓW WSCHODNICH PRZECHOWYWANE W ARCHIWUM ARCHIDIECEZJALNYM W GNIEŹNIE
}

Schematyzmy kościelne, przygotowywane dla poszczególnych wspólnot diecezjalnych i zakonnych, są cennym źródłem historycznym ${ }^{1}$. Wydawane systematycznie stanowią statystyczny i prozopograficzny zapis przeszłości, który często jest nie do odtworzenia $z$ powodu utraty innych archiwaliów. Nie może zatem dziwić fakt, że druki te cieszą się sporym zainteresowaniem historyków, którzy opracowują je pod względem naukowym ${ }^{2}$, katalogują je $\mathrm{j}^{3}$, a także przygotowują

* Ks. Łukasz Krucki - dr historii Kościoła, pracownik merytoryczny w Archiwum Archidiecezjalnymw Gnieźnie, e-mail: krucki@op.pl

${ }^{1}$ E. Gigilewicz, Schematyzm, w: Encyklopedia katolicka, t. 17, red. E. Gigilewicz, Lublin 2012, kol. 1217.

${ }^{2}$ M. Banaszak, Elenchy i roczniki archidiecezji poznańskiej, „Miesięcznik Kościelny Archidiecezji Poznańskiej”, 26 (1975) nr 10-11, s. 251-254; J. Kopiec, Schematyzmy diecezji opolskiej z lat 1947-1974, „Archiwa Biblioteki i Muzea Kościelne” (dalej: ABMK), 61 (1992) s. 167-216; T. Krahel, Schematyzmy diecezji wileńskiej jako źródto historyczne (I), ABMK, 38 (1979) s. 111-149; tenże, Schematyzmy diecezji wileńskiej jako źródło historyczne (II), ABMK 39 (1979) s. 191-233; H. Kramarz, Schematyzmy galicyjskie jako źródto historyczne, „Studia Historyczne” (dalej: SH), 25 (1982) nr 1, s. 27-48; taż, Jeszcze raz w sprawie schematyzmów galicyjskich, SH, 28 (1985) z. 4, s. 633-635; taż, Schematyzmy galicyjskie (1776-1914) jako c.k. rocznik sprawozdawczy dotyczacy obsady kadrowej władz, urzędów, towarzystw i instytucji, ,Rocznik Historii Prasy Polskiej”, 10 (2007) z. 1 (19), s. 5-29; B. Kumor, Schematyzmy diecezji tarnowskiej z XIX w. jako źródło demograficzne, „Przeszłość demograficzna Polski”, 1 (1967) s. 67-87; A. Kwaśniewski, Rubrycele i schematyzmy diecezji kieleckiej (1808-1818), „Rocznik Oddziału Polskiego Towarzystwa Historycznego w Skarżysku-Kamiennej. Z dziejów regionu i miasta”, 4 (2013) s. 57-77; A. Mańkowski, O dawnych rubrycelach chetmińskich, „Miesięcznik Diecezji Chełmińskiej”, 78 (1935) s. 552-556; G. Zamoyski, Schematyzmy diecezji przemyskiej obrządku tacińskiego jako źródto statystyczno-kartograficzne, „Rocznik Przemyski”, 41 (2005) z. 4, s. 127-142.

${ }^{3}$ E. Chomentowska, Katalog rubrycel $i$ schematyzmów zakonów męskich i żeńskich obszaru historycznych ziem Rzeczpospolitej za lata 1690-2008 w zbiorze Biblioteki Uniwersyteckiej Kato- 
ich kopie edytorskie, opatrzone stosownym aparatem krytycznym ${ }^{4}$. Niestety, uwaga owych badaczy skupia się zasadniczo na schematyzmach opracowanych dla potrzeb diecezjalnych i zakonnych Kościoła rzymskokatolickiego. Druki te są bowiem powszechnie znane, łatwo dostępne i najbardziej przydatne przy zgłębianiu dziejów Kościoła na ziemiach polskich. Powszechnie obrany kierunek rodzi jednak niebezpieczeństwo pominięcia istotnej grupy druków, a mianowicie schematyzmów Kościołów katolickich obrządków wschodnich, które tak jak ich rzymskokatolickie odpowiedniki stanowią ważne źródło dla poznania wspólnot eklezjalnych, które choć wywodzą się z tradycji Kościołów wschodnich, to jednak w określonym momencie dziejowym zdecydowały się na zawarcie unii z Rzymem. Fakt ten mimowolnie wpływał na latynizowanie się owych Kościołów, a przez to przyczyniał się do przejmowania wzorców, które sprawdziły się w administracji i duszpasterstwie Kościoła rzymskokatolickiego. Przykładem takiej akomodacji są między innymi schematyzmy, druki przygotowywane przez administrację greckokatolicką i ormiańską. Publikacje te są jednak prawie nieznane. Przemilczeli je nawet w swoich opracowaniach tak wytrawni badacze jak Stanisław Chodyński ${ }^{5}$ i Tadeusz Długosz ${ }^{6}$. Jedynym historykiem, który podjął się omówienia schematyzmu ormiańskiego był Zdzisław Obertyński ${ }^{7}$. Niedostatkowi temu należy zatem sprostać, przywracając nauce historycznej te cenne, lecz poniekąd niedocenione druki.

Przedmiotem opracowania są trzy schematyzmy przechowywane w Archiwum Archidiecezjalnym w Gnieźnie. Dwa z nich zostały przygotowane dla potrzeb Kościoła greckokatolickiego, funkcjonującego na dawnych ziemiach Rze-

lickiego Uniwersytetu Lubelskiego Jana Pawła II, ABMK, 100 (2013), s. 55-179; A. Kwaśniewski, Katalog rubrycel i schematyzmów polskich cystersów znajdujących się w księgozbiorze podręcznym Archiwum Diecezjalnego w Kielcach (1788-1816), „Hereditas Monasteriorum”, 1 (2012) s. 189-205; S. Librowski, Katalog rubrycel i schematyzmów diecezji i zakonów historycznej Polski znajdujących się w księgozbiorze podręcznym Archiwum Diecezjalnego we Włocławku. cz. 1, z. 1, ABMK, 23 (1971), s. 213-310; tenże, Katalog rubrycel i schematyzmów diecezji i zakonów historycznej Polski znajdujących się w księgozbiorze podręcznym Archiwum Diecezjalnego we Włocławku.cz. 1, z. 2, ABMK 24 (1972) s. 5-94; tenże, Katalog rubrycel i schematyzmów diecezji i zakonów historycznej Polski znajdujących się w księgozbiorze podręcznym Archiwum Diecezjalnego we Włocławku.cz. 1, z. 3, ABMK 25 (1972) s. 39-113; tenże, Katalog rubrycel i schematyzmów diecezji $i$ zakonów historycznej Polski znajdujących się w księgozbiorze podręcznym Archiwum Diecezjalnego we Włoctawku. cz. 1, z. 4, ABMK 26 (1973) s. 89-197; tenże, Katalog rubrycel i schematyzmów diecezji i zakonów historycznej Polski znajdujacych się w księgozbiorze podręcznym Archiwum Diecezjalnego we Włocławku. cz. 2, ABMK 27 (1973) s. 57-130

${ }^{4}$ M. Dębowska, Diecezja tucka i żytomierska w pierwszych latach istnienia. Wybrane zagadnienia, Lublin 2014; K. Śmigiel, Schematyzmy duchowieństwa niemieckiego w Wartheland 1939-1945, ABMK, 36 (1978), s. 371-385.

${ }^{5}$ S. Chodyński, Dyrektorium, directorium, w: Encyklopedia kościelna, t. 4, red. M. Nowodworski, Warszawa 1874, s. 416-420.

${ }^{6}$ T. Długosz, Schematyzmy diecezjalne jako źródto historyczne, „Sprawozdania z Czynności Wydawniczych TN KUL", 12 (1961) s. 86-89.

${ }^{7}$ Z. Obertyński, Na marginesie diecezjalnego schematyzmu ormiańskiego, „Sprawozdanie z Posiedzenia Towarzystwa Naukowego Warszawskiego", 26 (1933) z. 7/9, s. 203-214. 
czypospolitej, a więc archidiecezji lwowskiej (1858) i diecezji stanisławowskiej (1938), trzeci natomiast omawia ustrój i organizację archidiecezji lwowskiej obrządku ormiańskiego z okresu bezpośrednio poprzedzającego wybuch drugiej wojny światowej (1939).

Podkreślić należy, że omawiane schematyzmy są drukami niezwykle rzadkimi. Niewiele bibliotek może poszczycić się w ogóle posiadaniem tego typu publikacji. Najliczniejszy ich zbiór jest przechowywany w Bibliotece Uniwersyteckiej Katolickiego Uniwersytetu Lubelskiego Jana Pawła II. Katalog tejże biblioteki uwzględnia następujące elenchusy greckokatolickie przygotowane dla:

a) archidiecezji lwowskiej na lata: 1836, 1840, 1842-1845, 1848, 1850, $1852,1855-1868,1871,1872,1874-1882$ (w języku łacińskim) ${ }^{8}$ oraz na lata: 1882, 1883, 1886-1889, 1891-1901, 1903-1907, 1909-1912, 1914, 1924, 1928, 1930, 1932/33, 1938 (w języku ukraińskim)

b) archidiecezji lwowskiej i diecezji stanisławowskiej na rok 1885 (w języku ukraińskim) $)^{10}$;

c) diecezji przemyskiej na lata: $1828,1830,1831,1833,1835,1836,1838$, 1839, 1842-1846, 1848-1852 (w języku łacińskim) oraz na lata: 1868, 1869, 1873 1875, 1879-1881, 1883-1885 (w języku ukraińskim) ${ }^{11}$;

d) diecezji przemyskiej, samborskiej i sanockiej na lata: 1926, 1928, 1930, 1932, 1934, 1936-1938/1939 (w języku ukraińskim) ${ }^{12}$;

e) diecezji stanisławowskiej na lata: 1886, 1888, 1890, 1912, 1913, 19281933, 1935, 1938 (w języku łacińskim) ${ }^{13}$ oraz na lata: 1886, 1887, 1888, 1890, 1891, 1892, 1894-1907, 1909-1914, 1925, 1927, 1929, 1930, 1931, 1935, 1938 (w języku ukraińskim) $)^{14}$;

f) Administracji Apostolskiej Łemkowszczyzny na rok 1936 (w języku ukraińskim) ${ }^{15}$.

Wspomniana biblioteka posiada ponadto schematyzmy ormiańskie odnoszące się do archidiecezji lwowskiej obrządku ormiańskiego z lat: 1861, 1864, 1871, 1872, 1875, 1876, 1880, 1882, 1884-1892, 1894, 1897-1901, 1903, 1908-1912, 1914, 1918, 1920, 1924-1929, 1933-1935 (opracowane w języku łacińskim) ${ }^{16}$.

Nie oznacza to jednak, że i w innych placówkach archiwalnych, bibliotecznych, czy też muzealnych nie można odnaleźć pojedynczych tomów, a nawet całych serii tych druków. Znamiennym tego przykładem jest chociażby Muzeum Narodowe Ziemi Przemyskiej w Przemyślu, któremu udało się skolekcjonować znaczny zbiór elenchusów greckokatolickich przygotowanych dla potrzeb diecezji przemyskiej z lat: 1831, 1835, 1836, 1842, 1843, 1847, 1848, 1849, 1873,

\footnotetext{
${ }^{8} \mathrm{http}: / /$ dlibra.kul.pl/publication/16153 (dostęp: 21. 05. 2015 r.).

${ }^{9} \mathrm{http}: / /$ dlibra.kul.pl/publication/16275 (dostęp: 21. 05. $2015 \mathrm{r}$.).

${ }^{10} \mathrm{http}: / /$ dlibra.kul.pl/publication/16094 (dostęp: 21. 05. $2015 \mathrm{r}$.).

${ }^{11} \mathrm{http}: / /$ dlibra.kul.pl/publication/16275 (dostęp: 21. 05. $2015 \mathrm{r}$.).

${ }^{12} \mathrm{http}: / /$ dlibra.kul.pl/publication/16319 (dostęp: 21. 05. $2015 \mathrm{r}$.).

${ }^{13} \mathrm{http}: / /$ dlibra.kul.pl/publication/16070 (dostęp: 21. 05. 2015 r.).

${ }^{14} \mathrm{http}: / /$ dlibra.kul.pl/publication/16096 (dostęp: 21. 05. 2015 r.).

${ }^{15} \mathrm{http}: / /$ dlibra.kul.pl/publication/16436 (dostęp: 21. 05. $2015 \mathrm{r}$.).

${ }^{16} \mathrm{http}: / /$ dlibra.kul.pl/publication/13678 (dostęp: 21. 05. 2015 r.).
} 
1882, 1884, 1890, 1892, 1893, 1897, 1898-1900, 1903, 1912, 1914, 1918, 1926, 1928-1930, 1932, 1934, 1936-1938/1939 ${ }^{17}$. Niemniej, schematyzmy te nadal pozostają drukami mało znanymi, stąd też w ostatnim czasie prowadzi się akcję ich digitalizacji i zamieszczania na platformie bibliotek cyfrowych, aby w ten sposób ułatwić badaczom dostęp do tego rodzaju źródła.

Poruszając problematykę schematyzmów Kościołów katolickich obrządków wschodnich nie sposób nie odnieść się do ich tradycji. Druki te pojawiły się później niż ich łacińskie odpowiedniki, ale przez to przejęły od nich strukturę i charakter $^{18}$. Jako pierwsze zaczęły ukazywać się w Kościele greckokatolickim, funkcjonującym w granicach monarchii austriackiej. W 1814 r. został opublikowany elenchus diecezji mukaczowskiej, a następnie zaczęły ukazywać się - przygotowywane po łacinie, później w języku ukraińskim - schematyzmy diecezji przemyskiej (od 1828 r.), archidiecezji lwowskiej (od 1832 r.), diecezji kryrzowieckiej w Jugosławii (od 1832 r.), diecezji na Bukowinie (od 1841 r.), diecezji preszowskiej (od 1848), diecezji stanisławowskiej (od 1886 r.) oraz diecezji hajduoroskiej na Węgrzech (od 1918 r.). W 1936 r. ukazał się schematyzm Apostolskiej Administracji Łemkowszczyzny. Ostatnie schematyzmy greckokatolickie ukazały się w 1944 r. we Lwowie oraz w 1948 r. w Preszowie. Ponownie zaczęto powracać do praktyki ich wydawania dopiero po 1991 r., a więc po upadku ZSRR ${ }^{19}$.

Później aniżeli Kościół greckokatolicki zaczął wydawać swoje elenchusy Kościół ormiański. Pierwszy taki druk, opracowany dla potrzeb archidiecezji lwowskiej obrządku ormiańskiego, ukazał się najprawdopodobniej w $1861 \mathrm{r}$. Impulsem dla jego powstania był konflikt, który toczył się między zwolennikami likwidacji obrządku ormiańskiego na ziemiach polskich, a obrońcą dotychczasowego porządku, ks. Isaakiem Isakowiczem, późniejszym arcybiskupem lwowskim ob. orm. Spór ten mimowolnie wpłynął na ożywienie tradycji ormiańskiej, a przez to zaowocował chęcią precyzyjnego określenia własnych struktur eklezjalnych ${ }^{20}$. Praktyka zainicjowana w $1861 \mathrm{r}$. z powodzeniem była kontynuowana do wybuchu drugiej wojny światowej ${ }^{21}$.

Odnosząc się do schematyzmów Kościołów katolickich obrządków wschodnich, które znajdują się w Archiwum Archidiecezjalnym w Gnieźnie, należy

${ }^{17} \mathrm{http}: / /$ www.pbc.rzeszow.pl/dlibra/publication/11460 (dostęp: 21. 05. 2015 r.).

${ }^{18}$ Schematyzmy Kościoła rzymskokatolickiego, wydawane corocznie, wyłoniły się w 2. poł. XVIII w. z jeszcze wcześniej przygotowywanych rubrycel, czyli kalendarzy liturgicznych. Początkowo uwzględniały one jedynie spisy kanoników kapituł katedralnych oraz wykazy księży zmarłych w poprzednim roku (lub poprzednich latach). Na początku XIX w. zaczęto zamieszczać schematyzmach diecezjalnych spisy centralnych urzędów diecezjalnych oraz parafii, wraz ich obsadą. W XX w. schematyzmy stały się wydawnictwami samoistnymi o charakterze informatora statystyczno -prozopograficznego. Zob. Gigilewicz, Schematyzm, kol. 1217.

19 http://www.apokryfruski.org/archiwum/regiony/archiwum-nadsania/schematyzmy-diecezji -przemyskiej/ (dostęp: 22. 05. 2015 r.).

${ }^{20} \mathrm{http}: / /$ www.bu.kul.pl/ormianski-kosciol-katolicki-na-dawnych-ziemiach-polskich,art_11348. html (dostęp: 22. 05. 2015 r.).

${ }^{21}$ Zob. Schematismus archidioecesis Leopoliensis ritus armeno-catholici pro anno Domini 1939, Lwów 1939. 
stwierdzić, że są to druki zgromadzone w sposób przypadkowy. Niemniej stanowią cenne źródło poznawcze. O ile elenchusy greckokatolickie z lat 1858 (z archidiecezji lwowskiej) i 1938 (z diecezji stanisławowskiej) można zlokalizować chociażby we wspomnianej Bibliotece Uniwersyteckiej KUL, to schematyzm ormiański z 1939 r. pozostawał dotychczas właściwie nieznany. Przy tej okazji koniecznym staje się jednak zaprezentowanie spostrzeżeń odnoszących się do tych publikacji. Pierwsze z nich odnosi się do tytułów druków, czy to pisanych po łacinie, czy też w języku ukraińskim, gdyż nawiązują one bezpośrednio do tytulatury stosowanej w publikacjach proweniencji rzymskokatolickiej. Na tym nie kończą się podobieństwa, gdyż redaktorzy tychże schematyzmów, wywodzący się najprawdopodobniej z centralnych urzędów administracyjnych diecezji, zachowali układ i tematykę odpowiadającą elenchusom łacińskim. Zaowocowało to umieszczeniem w nich następujących części składowych: not o najwyższych hierarchach Kościoła powszechnego i o władzach własnego Kościoła partykularnego (archidiecezji lwowskiej ob. gr., diecezji stanisławowskiej ob. gr., archidiecezji lwowskiej ob. orm.), spisów kanoników kapituł katedralnych (gremialnych i honorowych), zestawień centralnych urzędach diecezjalnych (konsystorz, trybunał kościelny, seminarium), wykazów egzaminatorów i sędziów prosynodalnych, itp. Największą objętościowo część stanowią każdorazowo informacje odnoszące się do poszczególnych parafii zamieszczanych według organizacji dekanalnej. Dane te uwzględniają kwestie patronatu, liczby kaplic, szkół, szpitali oraz oczywiście podaje liczbę wiernych. Niezwykle cenne okazują się w tej dziedzinie dane prozopograficzne duchowieństwa greckokatolickiego i ormiańskiego, zaangażowanego duszpastersko w określonych wspólnotach parafialnych. Uwzględniają one daty urodzin, święceń oraz instalacji na urząd. Specyfiką tych druków są informacje o zawartym małżeństwie, co nie pojawia się ze względów oczywistych w schematyzmach rzymskokatolickich. Na tym właściwie kończy się indywidualizm omawianych druków, gdyż pozostałe elementy - spisy zakonników, alumnów, zmarłych kapłanów w roku wcześniejszym, czy też sumaryczne zestawienie stanu diecezjalnego - są kalkami z publikacji katolickich.

Przechowywane w Archiwum Archidiecezjalnym w Gnieźnie schematyzmy Kościołów katolickich obrządków wschodnich stanowią bezsprzecznie cenne źródło do poznania greckokatolickich i ormiańskich wspólnot eklezjalnych. Należy je wobec tego przywrócić nauce historycznej, aby zawarte w nich informacje mogły służyć kolejnym generacjom badaczy, zgłębiającym dzieje ustroju i organizacji Kościołów zunifikowanych z Rzymem w czasie niewoli narodowej i w okresie II Rzeczpospolitej. 


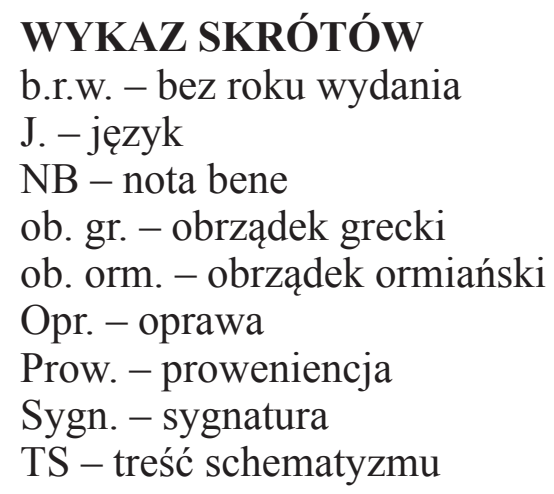

\section{KOŚCIÓŁ GRECKOKATOLICKI}

W 1596 r. została zawarta w Brześciu Litewskim unia między Kościołem katolickim a Cerkwią prawosławną funkcjonującą w Rzeczpospolitej Obojga Narodów. W jej wyniku powstał tzw. Kościół unicki. Bez większych przeszkód funkcjonował on do czasu rozbiorów Rzeczpospolitej. W XIX w. Kościół unicki zorganizowany na ziemiach, które weszły w skład imperium rosyjskiego został zdelegalizowany $(1839,1875)$; względną swobodą cieszył się w Galicji, należącej do monarchii Habsburgów. Tam też przyjął nazwę Kościoła greckokatolickiego, stając się jednocześnie symbolem rodzącej się tożsamości ukraińskiej. Swoim zasięgiem objął on wówczas i inne ziemie Austro-Węgier. W 1946 r. w ramach represji sowieckich zlikwidowano Kościół greckokatolicki na ziemiach włączonych do ZSRR. Zaczął się on odradzać na Ukrainie po 1991 r.

\subsection{Archidiecezja (archieparchia) greckokatolicka we Lwowie}

W 1677 r., po przystąpieniu prawosławnej diecezji lwowsko-halickiej do unii brzeskiej, we Lwowie została utworzona diecezja Kościoła unickiego. W 1807 r. podniesiono ją do rangi archidiecezji, a w roku następnym została ustanowiona metropolią. W 1885 r. z terytorium archidiecezji lwowskiej wyłączono diecezję stanisławowską ob. gr. W 1946 r., na tzw. synodzie lwowskim, podjęto decyzję o likwidacji archidiecezji lwowskiej ob. gr. Papież Jan Paweł II reaktywował ją w $1991 \mathrm{r}$.

Schematismus universi venerabilis cleri archidioeceseos metropolitanae Leopoliensis pro anno Domini 1858, Leopoli b.r.w., E Typographia Instituti Stauropigiani, $21 \mathrm{~cm}$, ss. $255+[1]$.

TS: nota o kard. Michale Lewickim, wykaz ordynariuszy diecezji lwowskiej ob. gr., nota o bp. pomocniczym - Spiridionie Litwinowiczu, spis kanoników gremialnych i honorowych kapituły lwowskiej ob. gr., wykazy pracowników instytucji centralnych: konsystorza, trybunału kościelnego, seminarium duchownego, komisji instytutu „Viduarum et Orphanorum” („Wdów i sierot”), egzaminatorzy archidiecezjalni, dziekani emeryci, księża wysłani na studia specjalistyczne, a także pojedyncze osoby: sekretarz ordynariusza, dyrektor domu rekolekcyjnego, dyrektor Biblioteki Archikatedralnej oraz administrator parafii św. Barbary w Wiedniu.

„Status beneficiorum et cleri curati”, czyli szczegółowe wyliczenie wszystkich parafii archidiecezji lwowskiej ob. gr., z uwzględnieniem podziałów administracji państwowej (cyrkuły) oraz kościelnej (dekanaty); spisy miejscowości przynależnych do poszczegól- 
nych parafii, patronat, liczbę wiernych, liczbę kaplic, szkół i szpitali. Przy poszczególnych parafiach zostali uwzględnieni kapłani w nich pracujący, wraz z niezbędnymi danymi (data urodzenia i święceń) oraz adnotacją „ux.” - „uxoratus” (żonaty).

Ponadto wymieniono księży nieżonatych, księży jubilatów, księży bez oficjum, księży wyświęconych w 1857 r., zakonników (bazylianów) przebywających w różnych monastyrach, spis alumnów Generalnego Seminarium Duchownego we Lwowie, spis zmarłych kapłanów w 1857 r., zestawienie sumaryczne stanu archidiecezji, appendix: Relationes certis anni temporibus per Decanos foraneos ad Consistorium praestande, indeksy: dekanatów, osób, miejscowości, errata.

J.: łaciński.

Sygn.: brak

NB.: stan dobry; niewielkie ślady zalania i zawilgocenia, pozaginane „rogi” kart druku.

Prow.: ,ad Celarski” i data: 12 IV 1858.

Opr.: papierowa, oryginalna.

\subsection{Diecezja (eparchia) greckokatolicka w Stanisławowie}

Zabiegi o utworzenie grekokatolickiej diecezji w Stanisławowie (obecnie: Iwano-Frankowsk) czynił na początku XIX w. biskup Anton Anhełłowycz. Nie przyniosły one jednak żadnego efektu. W 1848 r. do pomysłu tego wrócili Michał Lewicki, arcybiskup metropolita lwowski ob. gr., oraz Grzegorz Jachimowicz, biskup przemyski ob. gr. W 1850 r. udało im się uzyskać aprobatę cesarza Franciszka Józefa I, który 8 V 1850 r. wydał rozporządzenie o utworzeniu greckokatolickiej diecezji w Stanisławowie. Zatwierdzenie kanoniczne, dokonane przez Leona XIII, nastąpiło dopiero 26 IX 1885 r. Organizatorem i pierwszym biskupem diecezji został Julian Pepesz (1885-1891). W 1946 r. diecezja stanisławowska została zlikwidowana przez władze sowieckie. Ponowna jej erekcja, jako diecezji iwano-frankowskiej, nastąpiła w 1991 r. W 2011 r. Benedykt XVI podniósł ją do rangi archidiecezji.

Шематизм всього кліру греко-католицької єпархії Станиславівської на рік

Божий 1938, Станиславів 1938, Накладом клира епархіяльного, 23 cm, ss. 216.

TS: tytuł diecezji - Dziewicy Maryi, nota o papieżu - Piusie XI, nuncjuszu - Filipie Cortesim, metropolicie lwowskim ob. gr. - Andrzeju Szeptyckim, bp. stanisławowskim ob. gr. - Grzegorzu Chomyszynie, bp. pomocniczym - Janie Latyszewskim, skład rady biskupiej, skład kapituły stanisławowskiej ob. gr., kanonicy honorowi, rada biskupia, kancelaria biskupia, egzaminatorzy prosynodalni, sąd biskupi, seminarium duchowne (profesorowie i alumni), kapłani na studiach specjalistycznych, kapłani w Ameryce, kapłani emeryci, prezbiterzy jubilaci, podział na dekanaty i powiaty.

Wykaz wszystkich parafii, który uwzględnia spisy miejscowości do nich przynależnych, patronat, liczbę wiernych greko-katolickich (a także rzymskich katolików i żydów), liczbę kaplic, szkół i szpitali. Przy poszczególnych parafiach zostali uwzględnieni kapłani w nich pracujący, wraz z niezbędnymi danymi (data urodzenia, święceń, instalacji kanonicznej) oraz adnotacją ,жен.” - żonaty. 
Ponadto wymieniono księży zakonnych (bazylianów) rezydujących w poszczególnych miejscowościach oraz siostry zakonne przebywające na terenie diecezji; zamieszczono spis zmarłych kapłanów w latach 1935-1938; zestawienie sumaryczne stanu diecezji na rok 1938 oraz indeksy osób i miejscowości.

J.: ukraiński.

Sygn.: brak.

NB.: stan dobry; niewielkie ślady zalania i zawilgocenia, naddarty grzbiet okładki.

Prow.: nieokreślona.

Opr.: papierowa, oryginalna.

\section{KOŚCIÓŁ KATOLICKI OBRZĄDKU ORMIAŃSKIEGO}

Pierwszym państwem, które przyjęło chrześcijaństwo jako religię obowiązującą była Armenia (301). Jako że chrześcijaństwo ormiańskie mocno było związane $\mathrm{z}$ tradycją monofizycką, stąd też zaliczane jest do grupy Kościołów przedchalcedońskich. Pod koniec XI w. Ormianie pojawili się na Rusi w okolicach Lwowa, stamtąd zaczęli migrować w inne rejony Europy Srodkowo-Wschodniej. Kościół rzymskokatolicki, pragnąc zachować jedność konfesyjną, zawarł w 1198 r. unię z Apostolskim Kościołem Ormian. Dotrwała ona do 1375 r., a następnie została wznowiona na Soborze Florenckim (1439), chociaż objęła niewielką liczbę Ormian. Trwałym wydarzeniem okazało się złożenie we Lwowie przez Mikołaja Torosowicza, biskupa lwowskiej diecezji Apostolskiego Kościoła Ormian, katolickiego wyznania wiary (1630). W 1635 r. zostało ono powtórzone Rzymie przed pap. Urbanem VIII. Fakt ten legł u podstaw Kościoła katolickiego obrządku ormiańskiego.

\subsection{Archidiecezja lwowska obrządku ormiańskiego}

Ormiańska diecezja lwowska została erygowana w 1356 r. Po złożeniu przez Mikołaja Torosowicza katolickiego wyznania wiary została podniesiona do rangi archidiecezji. Stopniowo ulegała latynizacji, czego symbolem stało się utworzenie w 1803 r. kapituły katedralnej. W okresie zaborów polityczną władzę rozciągnęli nad nią austriaccy Habsburgowie, po 1918 r. znajdowała się w granicach II Rzeczpospolitej, a od 1945 r. przynależała do ZSRR. Na skutek sowieckich represji wspólnota wiernych praktycznie przestała istnieć, stąd też po $1991 \mathrm{r}$. duszpasterstwo ormiańskokatolickie odrodziło się w niewielkim stopniu. Nie było ono w stanie przejąć nawet ormiańskiej katedry we Lwowie, którą w 2011 r. przekazano ukraińskiemu Apostolskiemu Kościołowi Ormiańskiemu.

Schematismus archidioecesis Leopoliensis ritus armeno-catholici pro anno Domini 1939, Leopoli b.r.w., Typis „Drukarnia literacka” (Sumptibus Curiae Metrop. Ritus Armeni), $21 \mathrm{~cm}$, ss. 48.

TS: patroni archidiecezji, nota o papieżu - Piusie XII, nuncjuszu - Filipie Cortesim, informacja o „sede vacante” po śmierci abp. Józefa Teodorowicza, wykaz hierarchów Kościoła łacińnkiego w Polsce, wykaz biskupów i arcybiskupów lwowskich ob. orm., skład kapituły lwowskiej ob. orm. (kanonicy gremialni i honorowi), obsada Kurii Metropolital- 
nej we Lwowie ob. orm. oraz sędziowie kościelni, cenzorzy ksiąg, członkowie komisji mieszanej ds. konserwacji zabytków.

Wykaz wszystkich parafii, który uwzględnia historię każdej; spisy miejscowości do nich przynależnych, patronat, liczbę kaplic, szkół i szpitali. Przy poszczególnych parafiach zostali uwzględnieni kapłani w nich pracujący, wraz z niezbędnymi danymi (data i miejsce urodzenia, data święceń oraz instalacji na urząd).

Ponadto wymieniono ormiańską parafię wojskową, księży pracujących poza archidiecezją, księży bez oficjum, emerytów, alumnów seminarium archidiecezjalnego, księży przebywających na studiach specjalistycznych, zakonników i zakonnice rytu ormiańskiego, członków stowarzyszeń religijnych, nekrolog zmarłych kapłanów w 1938 r. (w tym abpa Józefa Teodorowicza), indeks osób, spis alfabetyczny kościołów parafialnych i kapelanów, appendix (dane adresowe instytucji kościelnych).

J.: łaciński.

Sygn.: brak.

NB.: stan dobry; wzdłuż grzbietu okładki dwa otwory wykonane dziurkaczem.

Prow.: Akta Prymasa Polski.

Opr.: papierowa, oryginalna.

słowa kluczowe: schematyzmy, Kościoły katolickie obrządków wschodnich, Kościół greckokatolicki, Kościół ormiański, duchowieństwo greckokatolickie, duchowieństwo ormiańskie.

\section{BIBLIOGRAFIA}

\section{Źródla drukowane}

Schematismus archidioecesis Leopoliensis ritus armeno-catholici pro anno Domini 1939, Lwów 1939.

\section{Opracowania}

Banaszak M., Elenchy i roczniki archidiecezji poznańskiej, „Miesięcznik Kościelny Archidiecezji Poznańskiej”, 26 (1975) nr 10-11, s. 251-254.

Chodyński S., Dyrektorium, directorium, w: Encyklopedia kościelna, t. 4, red. M. Nowodworski, Warszawa 1874, s. 416-420.

Chomentowska E., Katalog rubrycel i schematyzmów zakonów męskich i żeńskich obszaru historycznych ziem Rzeczpospolitej za lata 1690-2008 w zbiorze Biblioteki Uniwersyteckiej Katolickiego Uniwersytetu Lubelskiego Jana Pawła II, „Archiwa Biblioteki i Muzea Kościelne”, 100 (2013) s. 55-179.

Dębowska M., Diecezja łucka i żytomierska w pierwszych latach istnienia. Wybrane zagadnienia, Lublin 2014.

Długosz T., Schematyzmy diecezjalne jako źródło historyczne, „Sprawozdania z Czynności Wydawniczych TN KUL”, 12 (1961) s. 86-89.

Gigilewicz E., Schematyzm, w: Encyklopedia Katolicka, t. 17, red. E. Gigilewicz, Lublin 2012, kol. 1217. 
Kopiec J., Schematyzmy diecezji opolskiej z lat 1947-1974, „Archiwa Biblioteki i Muzea Kościelne", 61 (1992) s. 167-216.

Krahel T., Schematyzmy diecezji wileńskiej jako źródło historyczne, „Archiwa Biblioteki i Muzea Kościelne”, 38 (1979), s. 111-149;

Krahel T., Schematyzmy diecezji wileńskiej jako źródło historyczne, „Archiwa Biblioteki i Muzea Kościelne”, 39 (1979) s. 191-233.

Kramarz H., Jeszcze raz w sprawie Schematyzmów galicyjskich, „Studia Historyczne”, 28 (1985), z. 4, s. 633-635.

Kramarz H., Schematyzmy galicyjskie (1776-1914) jako c.k. rocznik sprawozdawczy dotyczący obsady kadrowej władz, urzędów, towarzystw i instytucji, „Rocznik Historii Prasy Polskiej”, 10 (2007) z. 1 (19), s. 5-29.

Kramarz H., Schematyzmy galicyjskie jako źródło historyczne, „Studia Historyczne”, 25 (1982), nr 1, s. 27-48.

Kumor B., Schematyzmy diecezji tarnowskiej z XIX w. jako źródło demograficzne, „Przeszłość demograficzna Polski”, 1 (1967) s. 67-87.

Kwaśniewski A., Katalog rubrycel i schematyzmów polskich cystersów znajdujących się w księgozbiorze podręcznym Archiwum Diecezjalnego w Kielcach (1788-1816), „Hereditas Monasteriorum”, 1 (2012) s. 189-205.

Kwaśniewski A., Rubrycele i schematyzmy diecezji kieleckiej (1808-1818), „Rocznik Oddziału Polskiego Towarzystwa Historycznego w Skarżysku-Kamiennej. Z dziejów regionu i miasta", 4 (2013), s. 57-77.

Librowski S., Katalog rubrycel i schematyzmów diecezji i zakonów historycznej Polski znajdujących się w księgozbiorze podręcznym Archiwum Diecezjalnego we Włocławku, cz. 1, z. 1, „Archiwa Biblioteki i Muzea Kościelne”, 23 (1971), s. 213-310.

Librowski S., Katalog rubrycel i schematyzmów diecezji i zakonów historycznej Polski znajdujących się w księgozbiorze podręcznym Archiwum Diecezjalnego we Włocławku, cz. 1, z. 2, „Archiwa Biblioteki i Muzea Kościelne”, 24 (1972), s. 5-94.

Librowski S., Katalog rubrycel i schematyzmów diecezji i zakonów historycznej Polski znajdujących się w księgozbiorze podręcznym Archiwum Diecezjalnego we Włocławku, cz. 1, z. 3, „Archiwa Biblioteki i Muzea Kościelne”, 25 (1972), s. 39-113.

Librowski S., Katalog rubrycel i schematyzmów diecezji i zakonów historycznej Polski znajdujących się w księgozbiorze podręcznym Archiwum Diecezjalnego we Włocławku, cz. 1, z. 4, „Archiwa Biblioteki i Muzea Kościelne”, 26 (1973), s. 89-197.

Librowski S., Katalog rubrycel i schematyzmów diecezji i zakonów historycznej Polski znajdujących się w księgozbiorze podręcznym Archiwum Diecezjalnego we Włocławku, cz. 2, „Archiwa Biblioteki i Muzea Kościelne”, 27 (1973), s. 57-130.

Mańkowski A., O dawnych rubrycelach chełmińskich, „Miesięcznik Diecezji Chełmińskiej", 78 (1935), s. 552-556.

Obertyński Z., Na marginesie diecezjalnego schematyzmu ormiańskiego, „Sprawozdanie z Posiedzenia Towarzystwa Naukowego Warszawskiego", 26 (1933) z. 7/9, s. 203 214.

Śmigiel K., Schematyzmy duchowieństwa niemieckiego w Wartheland, 1939-1945, „Archiwa Biblioteki i Muzea Kościelne", 36 (1978) s. 371-385.

Zamoyski G., Schematyzmy diecezji przemyskiej obrządku łacińskiego jako źródło statystyczno-kartograficzne, „Rocznik Przemyski”, 41 (2005) z. 4, s. 127-142.

Internet

http://dlibra.kul.pl/publication/16153 (dostęp: 21. 05. 2015 r.). 
http://dlibra.kul.pl/publication/16275 (dostęp: 21. 05. 2015 r.). http://dlibra.kul.pl/publication/16094 (dostęp: 21. 05. 2015 r.). http://dlibra.kul.pl/publication/16275 (dostęp: 21. 05. 2015 r.). http://dlibra.kul.pl/publication/16319 (dostęp: 21. 05. 2015 r.). http://dlibra.kul.pl/publication/16070 (dostęp: 21. 05. 2015 r.). http://dlibra.kul.pl/publication/16096 (dostęp: 21. 05. 2015 r.). http://dlibra.kul.pl/publication/16436 (dostęp: 21. 05. 2015 r.). http://dlibra.kul.pl/publication/13678 (dostęp: 21. 05. 2015 r.). http://www.pbc.rzeszow.pl/dlibra/publication/11460 (dostęp: 21. 05. 2015 r.). http://www.apokryfruski.org/archiwum/regiony/archiwum-nadsania/schematyzmy-diecezji-przemyskiej/ (dostęp: 22. 05. 2015 r.).

http://www.bu.kul.pl/ormianski-kosciol-katolicki-na-dawnych-ziemiach-polskich,art_11348.html (dostęp: 22.05. 2015 r.).

\section{SCHEMATISMS OF THE CATHOLIC CHURCHES OF THE EASTERN RITES STORED IN THE ARCHDIOCESAN ARCHIVE IN GNIEZNO}

\section{Summary}

Among the schematisms stored in the Archdiocesan Archive in Gniezno (these are prints prepared for the Archdiocese of Gniezno, other Polish and foreign Roman Catholic dioceses, and religious orders) are three elenchus reports produced for the Catholic Churches of the Eastern rites, existing in the former Eastern Borderlands. Two of them relate to the organization of the Greek Catholic Church: Archdiocese of Lviv (1858) and the Diocese of Stanisławów (1938), while the third one presents the structure and operation of the Armenian Archdiocese of Lviv before the outbreak of World War II (1939). All of those prints, in their structure and content, resemble schematisms prepared for the Roman Catholic Church. They are thus valuable sources from which we can learn about history, political system, organization, and people working in different institutions and parishes of the Greek Catholic Church and the Armenian Church in the nineteenth and twentieth centuries.

Keywords: schematisms, the Catholic Churches of the Eastern rite, the Greek Catholic Church, the Armenian Church, the Greek Catholic clergy, the Armenian clergy 